\title{
PERFORMANCE OPTIMIZATION OF EXISTING BOILERS AT SHAKARGANJ LLIMITED, JHANG
}

\author{
Muhammad Sharif Tahir and Muhammad Waseem Irshad \\ DGM Engineering, Shift Engineer (Mechanical Dept.) \\ Shakarganj Limited, Toba Road, Jhang, Pakistan
}

\begin{abstract}
There are numerous well-documented phenomena that plague the efficient operation of bagasse boilers. Key Parameters that influence boiler combustion and operation are studied with the aid of combustion and flue gas analyzer. Combustion stability and efficiency is linked to various parameters such as fuel moisture and air temperatures supplied to the boiler and are investigated in this paper as part of a case study. The paper highlights number of modern developments that have been implemented at Shakarganj Limited, Jhang to optimize the existing boiler design to enhance the Boiler capacity from 65 tph to 80 tph. Along with that impact of various devices on performance improvement of boiler has been shown with experimental data for comprehensive evaluation of boiler operation and combustion efficiency. Results of suitable measures after installation of low cost retrofits to reduce losses including combustion instabilities, unburnt fuel, moisture in fuel and deposition of ash on tubes are also part of the paper.
\end{abstract}

Key Words: Bagasse, Boiler, Air Heater, Economizer, Spreaders, Bagasse Dryer, Ash Cyclones, Flue Gases

\section{INTRODUCTION}

Shakarganj incorporated

Limited, transform renew-able crops such as sugarcane into value added products comprising of refined sugar. It has the manufacturing facility in Jhang District. An increase in alternative uses of bagasse (i.e. cane wood, Bio fuel, $\mathrm{CO}_{2}$ \& Steel plant), has developed an interest in energy efficiency of which the boiler efficiency forms an essential part. The boiler efficiency not only depends on the boiler configuration and operation but also on the fuel being used. This paper describes a conventional sugar factory boiler, the analysis of boiler operation and describes the modifications applied for improving boiler efficiency.
Shakarganj has a capacity of 12000 TCD. Plant requires 263tph steam which includes 18tph steam required for the distillery. Sugarcane bagasse is used as boiler fuel containing 51 $52 \%$ moisture. Brief introduction of boilers is as under:

\section{Observations of Existing Boilers:}

The efficiency of the boiler at 75 tons/hr. (01 No. Boiler) was approx. 64-66\% @ NCV. Estimated losses due to: Unburnt 10 to $12 \%$ Radiation and convection losses: 6 to $8 \%$ Heat losses through stack: 18 to $20 \%$ High combustion instability was observed in boiler through furnace ash analysis i.e. Presence of unburnt bagasse particles in ash. High pressure losses at Ash Cyclones (16 mbar). Poor Air to Fuel ratio.

\section{REVIEW AND ANALYSIS OF BOILER OPERATION}

Major areas under analysis:

Boiler Configuration and Operation, Combustion stability, Boiler efficiency

Comprehensive evaluation of boilers was done considering the above mentioned areas with the help of Flue gas analyzer. Below table shows some results of evaluation:

\section{INSTALLATIONS/ \\ MODIFICATIONS APPLIED TO EXISTING BOILERS}

Based on the outcomes of evaluation, modifications in the existing boilers were 
applied. Modification and their results are discussed below.

\section{Installation of Boiler retrofits:}

Installation of $\mathrm{Re}$ Grit Re-

Firing system

Installation of Pulsating

Dampers

Installation of Over firing nozzles

Installation of Air distribution plate under the Grate Installation of Bio Gas burners Installation of Economizer
Modifications Applied:

Modification of Ash Cyclones

\section{RE GRIT RE FIRING SYSTEM:}

This system recovers the high unburnt bagasse from boiler through Ash hoppers and supplied with an Air duct from Secondary fan to push it in boiler furnace to use it again as fuel resulting in reduction in unburnt losses and saving bagasse.
Before System Installation:

Fly ash was blackish that means high unburnt bagasse in boiler. (Unburnt losses were $10 \%-12 \%)$

\section{After System Installation Benefits:}

This System is used to recover unburnt bagasse from boiler. Unburnt bagasse is again fired in furnace to burn. Losses due to un burnt fuel reduced to 4 to $6 \%$ and increasing boiler efficiency by $2 \%$.
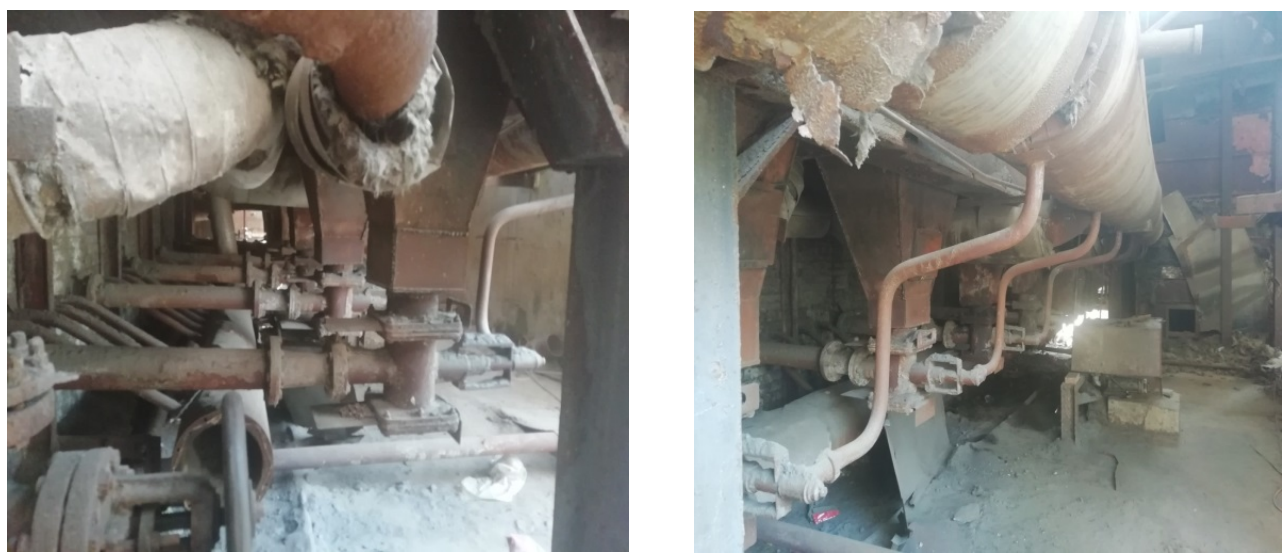

Re Grit Re Firing System installed at Boiler

\section{Bagasse Saving By Re Grit Re Firing System:}

Efficiency rise at average of $75 \mathrm{Ton} / \mathrm{hr}$ load

$=02 \%$

Steam Saving at 01 Boiler

Bagasse Saving at 01 Boiler

$=75 \times 0.02=1.5 \mathrm{Tons} / \mathrm{hr}$

Bagasse Saving at 02 Nos. Boilers

$=1.5 / 1.9=0.789 \mathrm{Tons} / \mathrm{hr}$

Bagasse Saving per day

$=0.789 \times 2=1.57 \mathrm{Tons} / \mathrm{Hr}$

Total amount saved per day

$=24 \times 1.57=37.89$ Tons $/$ day

$=3000 \times 37.89$ Rs 113,670/-

BAGASSE SPREADING AND FIRING SYSTEM:

Previously Bagasse spreading system was not so much efficient for feeding and spreading of bagasse over the full grate. Few improvements were done to make the existing system more efficient as below:

Improving the condition of the existing spreaders by proper adjustment facilities of guide plate from outside. Installation of pulsating dampers with common drive so that the bagasse will be more equalized spread over the depth of the furnace. Installation of over firing nozzles in side walls of furnace and fed with the air from secondary air fans. Installation of air baffle in hopper under the grate. Installation of twin roller feeders with picker roller in order to ensure continuous supply of bagasse and breaking of lumps so that fine particles can be spread.

PULSATING DAMPERS:

Shakarganj has installed 02 types of Pulsating dampers Internal Pulsating Dampers 


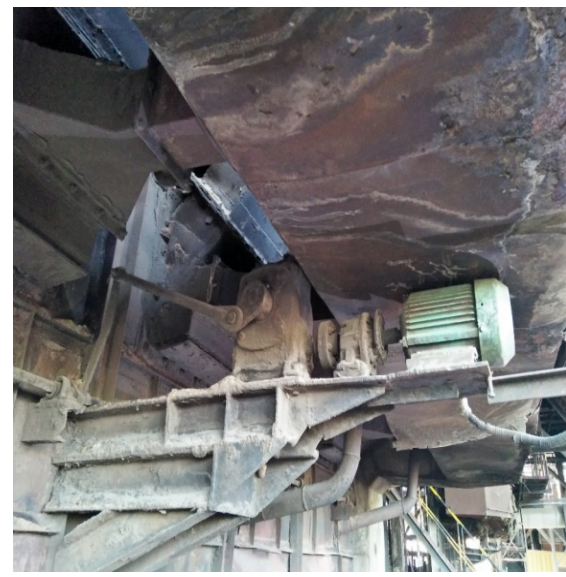

Internal Pulsating Dampers

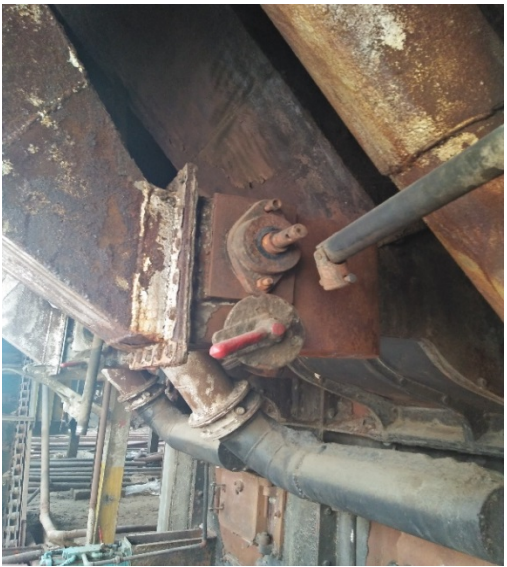

External Pulsating Dampers
BIO GAS BURNER:

As per previous practice biogas was blown into the boiler furnace without proper mixing it with combustion air. This resulted in in complete firing in boiler. Also resulting in high fouling and rapid corrosion of super heater.
Bio Gas Burner at Shakarganj:

Biogas burners (Wes man Design) with air supply through existing FD Fan have been installed.

Using this burner made combustion and temperature stable, also air to fuel ratio improved. Uniform spreading of Bio gas with boiler

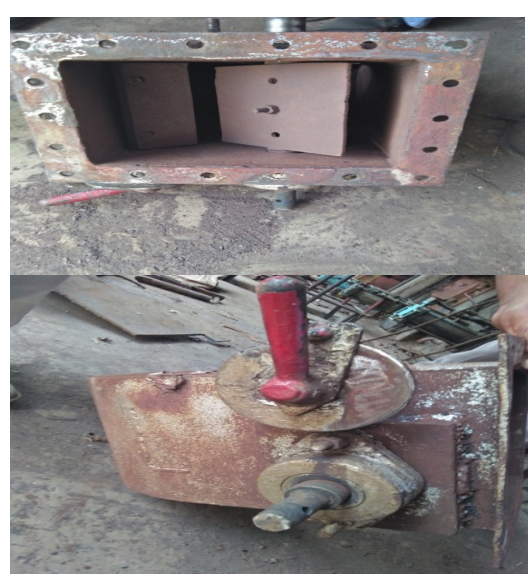

External Pulsating Dampers

tubes. Which burner in furnace, hence minimizing it's direct contact with boiler tubes. Which decrease corrosion of tubes.

Uniform spreading of Bio gas with burner in furnace, hence minimizing it's direct contact with boiler tubes. Which decrease corrosion of tubes.

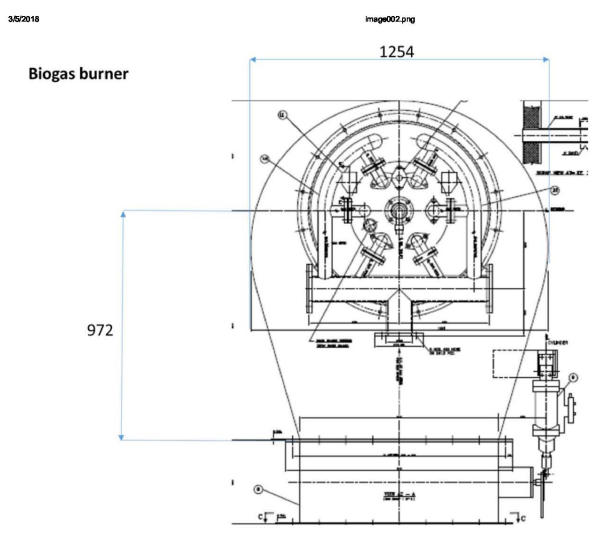

Bio Gas Burner Design

ECONOMIZER for Pre Heating of Boiler Feed Water:

Generally economizers are used to reduce energy consumption. In Boiler their function is to pre heat the boiler feed water temperature. Captures the waste heat from boiler flue gases and transfer it to the boiler feed water to raise the temperature up to $30^{\circ} \mathrm{C}$.

Economizer Installed at Shakarganj Boilers:

Shakarganj has installed economizers at 04 Nos. of boilers with heating surface of $320 \mathrm{~m}^{2}$. It raises the feed water temperature about $30^{\circ} \mathrm{C}$ from $100-105^{\circ} \mathrm{C}$ to $130-135^{\circ} \mathrm{C}$. Below is some calculated data for savings made by economizers. 
Efficiency Rise With $10^{\circ} \mathrm{C}$ temperature rise in feed water

$=01 \%$

Efficiency with $20^{\circ} \mathrm{C}$ temperature rise of feed water. (01 Boiler) $\quad=02 \%$

Steam Saving at One Boiler

Steam Saving at One Boiler

$=75 \times 0.02$

Bagasse Saving at One Boiler

$=1.5 \mathrm{Tons} / \mathrm{hr}$

Bagasse Saving at 04 Nos. Boiler

$=1.5 / 1.9=0.79 \mathrm{Tons} / \mathrm{hr}$

Bagasse Saving per day

Amount Saving

$=0.79 \times 4=3.16 \mathrm{Tons} / \mathrm{hr}$

$=24 \times 3.16=75.44$ Tons $/$ day

$=75.44 \times 3000$ Rs. 227,520

Below graph explicit the bagasse saving when compared with different parameters after evaluation.

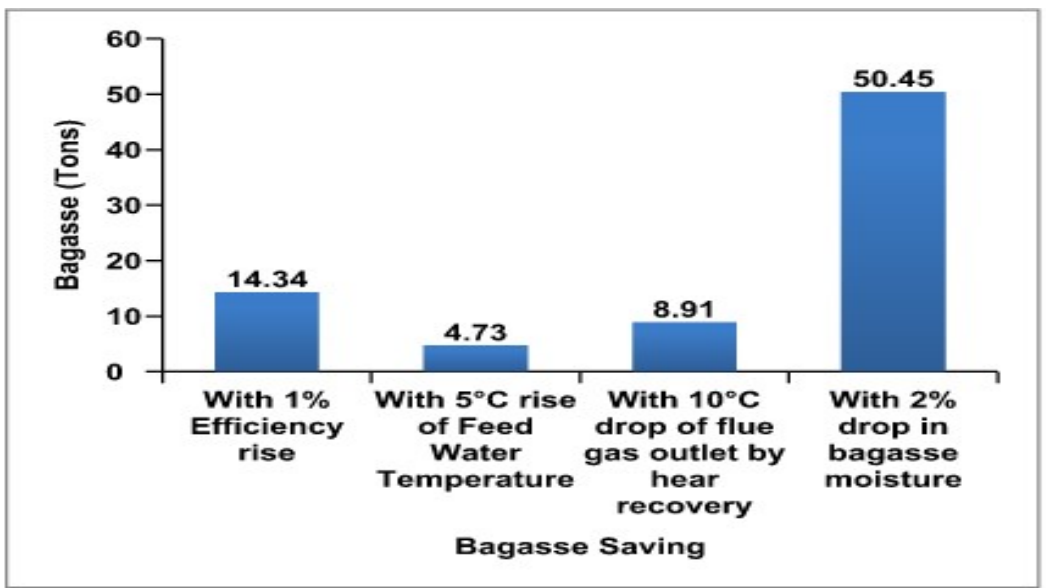

Fig.1 Bagasse saving vs Improved Boiler Parameters

THE ASH CYCLONES:

Smaller cyclones replaced with greater size $(5-6 \%$ of existing cyclones size) t2 Where allow a pressure drop of 8 mbar at 80 tph capacity.

\section{Problems Faced:}

Ash Cyclone size was too small. Boiler was running overpressure at higher loads which made difficult to keep the boiler load in control.

The angle of the swirls in cyclones was very small, which made the cyclone efficiency very low.

\section{Modifications:}

Size of cyclones increased (5$6 \%$ ) so that boiler can be run properly under pressure in furnace with maximum clearance. The angle of swirls also changed to improve the dust collection. Pressure drop of 8 mbar at $80 \mathrm{tph}$ capacity.

\section{CAPACITY}

\section{ENHANCEMENT OF I.D} FANS AT BOILER

Volumetric capacity of all ID fans enhanced to 5600 $\mathrm{m}^{3} / \mathrm{min}$ from $4750 \mathrm{~m}^{3} / \mathrm{min}$.

\section{BOILER EFFICIENCY}

Boiler efficiency is the percentage of heat input utilized in generation of steam. Efficiency of solid fuel boiler depends upon different factors like type of fuel, proper Where of fuel and combustion method. The easiest and most cost effective method is to calculate the efficiency value on five broad elements: Boiler stacks temperature,
Heat content of fuel, Fuel specification, Excess air levels \& ambient air temperature and relative humidity.

\section{Boiler Efficiency = Energy Steam - Energy BFW x100}

\section{Energy Fuel}

This method is known as direct method which is based on simply that efficiency is equal to output divide. Where by input. The other method is the indirect method of calculating boiler efficiency. To account the boiler losses a better and precise formula for efficiency calculation is given below:

$$
\mathbf{\eta}=\frac{M v}{N C V} \times 100
$$


Where

$M v=$ Heat transfer to steam

per kg of bagasse burnt

(Kcal/Kg)

$\mathrm{NCV}=$ Net calorific value

(Kcal $/ \mathrm{Kg}$ )

$M v=(N \cdot C \cdot V-Q) \cdot \alpha \cdot \beta \cdot \gamma$

Where

$Q=$ Sensible heat loss in flue gas $(\mathrm{Kcal} / \mathrm{Kg}$ )

a. $\beta . y=$ Co-efficient if $x$-tics of combustion efficiency

$\alpha=$ Co-efficient representing heat loss due to un-burnt 2solids.

$B=$ Co-efficient to account for heat losses by radiation.

$Y=$ Co-efficient of incomplete combustion.
For spreader stoker furnaces, its normal value $\alpha$ is taken as 0.975. $\beta$ value varies from 0.95 to 0.99 for more or less efficient lagging. $\mathrm{y}$ value is taken as 0.97 .

$\mathrm{Q}=[(1-\mathrm{M}) \times(1.4 \mathrm{RA}-0.13)+$ $0.5] \mathrm{t}$

Where:

$\mathrm{M}=\%$ Moisture in Bagasse

$\mathrm{RA}=$ Ratio of excess Air

$\mathrm{t}=$ Temperature of Flue gases

Here RA is ratio of excess air usually taken 1.45 for bagasse.

\section{Calorific Value:}

There are two different calorific values, a gross calorific value (GCV) and a net calo calorific rific value (NCV).
The GCV is the total energy released during the combustion process and can only be accurately determined by using a bomb calorimeter.

The NCV is the GCV minus the latent heat of the water formed by the combustion process and is obtained by calculation. The experimental procedure and method of calculation are laid down in ISO 1928 (Anon 1995).

Some comparison of bagasse NCV vs Moisture is shown in below graph:

The Boiler efficiency is also linked with flue gas temperature at the outlet. Trend with comparison is shown as below.

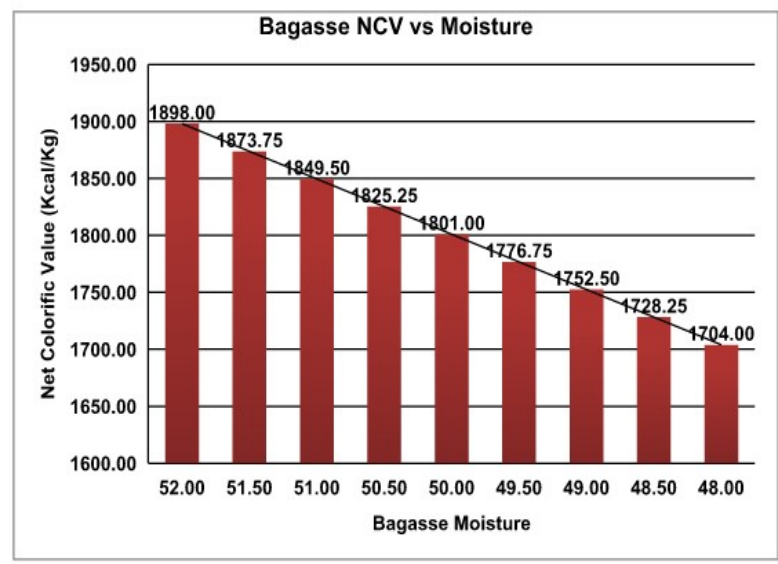

Fig.2 Bagasse NCV vs Moisture

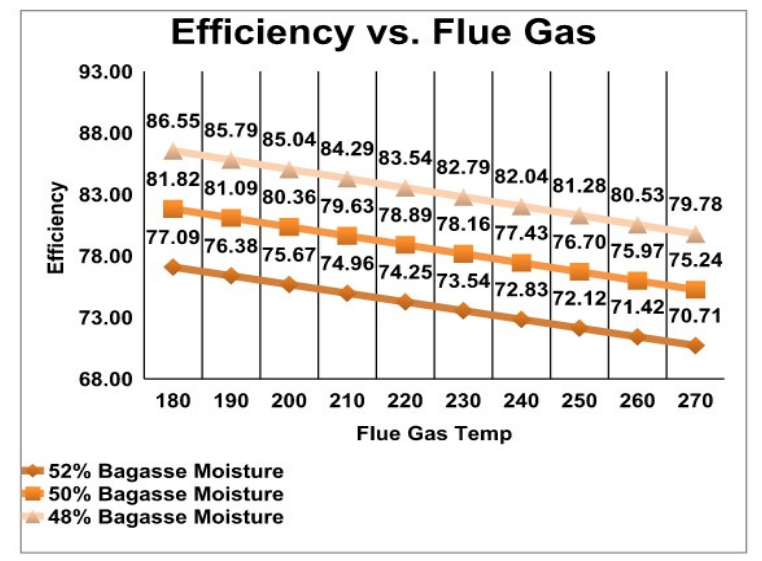

Fig.3 Boiler Efficiency vs Flue Gas Temp.

\section{CONCLUSION}

The modifications done in the existing boilers system has given much improvement and benefits for performance optimization and efficiency enhancement of existing boilers. i.e.

Boiler Efficiency:

Increase from $66 \%$ to $76 \%$

Re Grit Re-Firing System:

Increased efficiency by $2 \%$

Bagasse
Saving 37.89 Tons/Day

Un burnt losses reduced 4-6\%

Pulsating dampers: Uniform spreading of bagasse 
Bio Gas Burner:

Complete Combustion of bio gas, Minimized corrosion formation on tubes

\section{Economizer:}

$20^{\circ} \mathrm{C}$ Feed Water Temperat-

ure raise

$02 \%$ efficiency rise

Bagasse Saving 75.44 Tons/

Day

Increase in size of Ash

\section{Cyclones:}

Boiler runs under pressure

\section{Boiler Efficiency:}

Increase from $66 \%$ to $76 \%$ Re-Grit Re-Firing System: Increased efficiency by
2\% Bagasse Saving 37.89

Tons/Day

Unburnt losses reduced 4-6\%

Pulsating dampers:

Uniform spreading of bagas calorific se

Bio Gas Burner:

Complete Combustion of bio gas Minimized corrosion formation on tubes calorific

\section{Econ calorific omizer:}

$20^{\circ} \mathrm{C}$ Feed Water Temperature raise $02 \%$ efficiency rise Bagasse Saving 75.44 Tons/ Day Increase in size of Ash

\section{Cyclones:}

Boiler runs under pressure

\section{ACKNOWLEDGMENT}

At the end I would like to thank Shakarganj Limited Top Management especially $\mathrm{Mr}$. Javed Alam (EVP-Sugar Division) and Mr. M Sharif Tahir (DGM Engineering) for providing me an opportunity support and guidance with their versatile experience \& knowledge, to complete the project. I would also thank Pakistan Society of Sugar Technologists for their encouragement and providing me an opportunity to present the

Table-1 Boilers Installed at Shakarganj

\begin{tabular}{|c|c|c|c|c|c|c|}
\hline Design & Type & $\begin{array}{c}\text { Heating } \\
\text { Surface } \\
\left(\mathrm{m}^{2}\right) \\
\end{array}$ & $\begin{array}{c}\text { Steam } \\
\text { Production } \\
\text { (Tons/Hr.) }\end{array}$ & $\begin{array}{c}\text { Type of } \\
\text { Fuel }\end{array}$ & $\begin{array}{l}\text { Operating } \\
\text { Pressure } \\
\mathrm{Kg} / \mathrm{cm}^{2} \\
\end{array}$ & $\begin{array}{c}\text { Operating } \\
\text { Temperature }\end{array}$ \\
\hline Babcock \& Wilcox & \multirow{5}{*}{$\begin{array}{l}\text { Water } \\
\text { Tube } \\
\text { Boiler }\end{array}$} & 1,361 & 40 & \multirow{5}{*}{$\begin{array}{l}\text { Bagasse/ } \\
\text { Bio Gas/ } \\
\text { Sui Gas/ } \\
\text { Furnace Oil }\end{array}$} & \multirow[t]{5}{*}{25} & \multirow[t]{5}{*}{$350{ }^{\circ} \mathrm{C}$} \\
\hline FCB Franc & & 2,071 & 80 & & & \\
\hline Yoshimini Japan & & 2,220 & 80 & & & \\
\hline Yoshimini Japan & & 2,220 & 80 & & & \\
\hline Yoshimini Japan & & 2,220 & 80 at NCR & & & \\
\hline
\end{tabular}

Table-2 Evaluation Results with Flue Gas Analyzer

\begin{tabular}{|l|c|l|c|}
\hline \multicolumn{1}{|c|}{ Description } & Value & \multicolumn{1}{c|}{ Description } & Value \\
\hline Furnace Pressure & $\begin{array}{c}-4.38 \\
\mathrm{~mm} 2 \mathrm{O}\end{array}$ & $\begin{array}{l}\text { Flue Gas Outlet } \\
\text { Temperature Boiler }\end{array}$ & $321^{\circ} \mathrm{C}$ \\
\hline $\begin{array}{l}\text { Flue Gas Temperature Outlet Flue } \\
\text { Gas Arrestor }\end{array}$ & $187^{\circ} \mathrm{C}$ & $\begin{array}{l}\text { Air Temperature Air to } \\
\text { Grate }\end{array}$ & $173^{\circ} \mathrm{C}$ \\
\hline O2 Flue Gas Outlet Boiler & $\begin{array}{c}2.8 / 3 \\
\text { Vol\%dry }\end{array}$ & CO Flue Gas Outlet Boiler & $2500 \mathrm{ppmv}$ \\
\hline O2 Flue Outlet ID Fan & $\begin{array}{c}5.8-6.8 \\
\text { Vol\%dry }\end{array}$ & CO Outlet ID Fan & $\begin{array}{c}2000-8000 \\
\mathrm{ppmv}\end{array}$ \\
\hline $\begin{array}{l}\text { Flue Gas Pressure at ID Fan } \\
\text { suction }\end{array}$ & $-2 \mathrm{mbar}$ & $\begin{array}{l}\text { Flue Gas Pressure at } \\
\text { Outlet ID Fan }\end{array}$ & $-18 \mathrm{mbar}$ \\
\hline $\begin{array}{l}\text { Air Pressure at Outlet FD } \\
\text { Fan }\end{array}$ & $16 \mathrm{mbar}$ & $\begin{array}{l}\text { Air Pressure at Outlet } \\
\text { Secondary Air Fan }\end{array}$ & $20 \mathrm{mbar}$ \\
\hline $\begin{array}{l}\text { Pressure Drop Over Fly Ash } \\
\text { Arrestor }\end{array}$ & $\begin{array}{l}\text { Calculated Pressure Drop } \\
\text { Over Fly Ash Arrestor }\end{array}$ & $16.4 \mathrm{mbar}$ \\
\hline
\end{tabular}




\section{REFERENCES}

Cengel, A. Yunus, 20.15. Heat and Mass Transfer Fundamentals \& Applications, 5th Edition, McGraw-Hill Education, New York.

WIENESE, A. Boilers, Boiler Fuel and Boiler Efficiency, Sugar Milling Research Institute, Durban 4041, South Africa

Adriano V. Ensinas; Silvia A. Nebra, Energy Department - State University of Campinas Miguel A. Lozano; Luis Serra, Mechanical Engineering Department - University of Zaragoza Analysis of Cogeneration Systems In Sugar Cane Factories - Alternatives Of Steam And Combined Cycle Power Plants

DESCON 2011. Engineering Limited, Efficiency Improvement in Existing 80 Ton/Hr. Bagasse Fired Low Pressure Boiler. Paper in $45^{\text {th }}$ Annual Convention PSST.

http://www.scielo.br/scielo.php?script=sci arttext\&pid=S0104-66321998000100006

https://boilersinfo.com/increase-boiler-efficiency/ 